\title{
Harmonization of accounting for public sector entities in accordance with the leading international standards: a comparison of Italy and Ukraine
}

\author{
Mariya Lalakulych \\ Uzhgorod Trade and Economic Institute of the Kyiv National Trade and Economic University \\ Korynyanska str. 4, 8020 Uzhhorod \\ Ukraine \\ e-mail: info@utei-knteu.org.ua \\ Igor Britchenko \\ State Higher Vocational School Memorial of Prof. Stanislaw Tarnowski \\ Henryka Sienkiewicza 50, 39-400, Tarnobrzeg \\ Poland \\ e-mail: ibritchenko@gmail.com \\ Tetyana Hushtan \\ Department of Commodity Studies and Business \\ Uzhgorod Trade and Economic Institute of the Kyiv National Trade and Economic University \\ Korynyanska str. 4, 8020 Uzhhorod \\ Ukraine \\ e-mail: secretary-utei@ukr.net
}

\begin{abstract}
In recent years, there have been many reforms in the field of accounting. In the same time, scientists focus on the leading methods of accounting, financial management and economic opportunities for the additional use of accounting tools to introduce reforms in the field of the accounting of public sector entities. The main goal of this paper is to reveal the leading features of the accounting system of public sector entities and to study the aspects of a new accounting system, which in the future can be implemented into the activities of public sector entities.

The paper provides a scientific vision of the accounting reform of public sector entities. Our vision of forming a new accounting system in the public sector is based on the accounting model used in Italy and takes into account the peculiarities of the methodology and accounting organization in accordance with the International Accounting Standards. We highlight the main problems of introducing a new accounting system for public sector entities, based on the International Accounting Standards. In our opinion, this research can form new knowledge in the national literature on the accounting of public sector entities and highlight the main problems that arise while implementing accounting reforms. In addition, our research results can serve as a basis for the implementation of the accounting of public sector entities on the basis of International Accounting Standards for the public sector and the accrual principle. We believe that the main scientific aspects of public sector accounting will be the basis for future reforms based on the implementation of International Accounting Standards in the activities of public sector entities.
\end{abstract}

\section{Introduction}

In modern conditions of economic activity in society there are frequent economic and political reforms that lead to changes in accounting paradigms in public sector entities (Hood 1995). The recent financial crises have emphasized the need for accounting reforms in the public sector; as a result of such reforms, the International Accounting Standards require the introduction of various types of economic activities and forms of ownership including public sector entities into the activities of economic entities (Pettigrew 1997). This process aims to meet the needs of different users of information (shareholders, participants, owners, etc.). The result of such an economic process is the introduction of a unified "accounting language", "globally" carry out political decisions (European Commission 2013).

The harmonization of accounting involves certain conformity and coherence, compliance with the principles of accounting, reporting by a group of countries or their associations, for example, the countries of the European Union, the Commonwealth of Independent State (Cañibano and Mora 2000; Di Pietra 2000; Jackson and Lapsley 2003; Lapsley and Wright 2004; Kunitsyna et al. 2018; or Masiulevičius and Lakis 2018). 
Harmonization involves the combination and mutual compliance of the laws of the countries with regard to the regulation of accounting, the existence of its model of accounting organization and a system of standards in each country. Accounting for public sector entities is at the stage of active reforming aimed at bringing its theory and practice closer to international accounting standards for the public sector accounting of the world community. In the literature, readers can see a significant amount of research on harmonization in the field of the accounting of public sector entities (Van Der Tas et al. 1992; Čábelková et al. 2015; Moyseyenko and Ryvak 2016; Britchenko et al. 2018; or Subačiene et al. 2018). The main task of harmonization in the field of accounting is that the implemented international standards do not differ significantly from similar standards in other member countries of the community, that is, they are in harmony with each other. The countries of the European Economic Community, which published a number of normative documents, called the Directives, or the Laws of the European Economic Community, went so far. They are mandatory for implementation in all countries of the European Economic Community. This approach to unification of accounting relates to the regional level (Di Pietra 2000; Kalyugina et al. 2015). International studies also detail the level of unification achieved after the reform of accounting harmonization (Van Der Tas et al. 1992). The harmonization of accounting involves the establishment of uniform norms and requirements for accounting, the application of a unified set of standards governing the accounting event and its representation in the reporting. Harmonization enables globalization of accounting policies, principles and accounting and reporting systems.

However, governments around the world are making some more progressive efforts to introduce harmonized accounting systems for public sector entities based on International Accounting Standards. The research analyzes ongoing reforms in accounting for public sector entities in Italy. The Italian experience is a reform of harmonization that directs the government to conduct harmonized accounting on the basis of International Accounting Standards for the public sector and accrual accounting (Benito et al. 2007). The need for the harmonization of accounting is determined primarily by the development of processes of economic integration of countries. The implementation of the International Accounting Standards is an important prerequisite for the effective operation and recognition of public sector accounting at the international level.

\section{Research on accounting reforms: literature review}

The purpose of the reform is to improve the system of accounting and financial reporting in the public sector, taking into account the requirements of international standards. To achieve this goal, it is supposed: to develop and implement International Standards in Public Sector Accounting; to create a single plan of accounts in the public sector, harmonized with the budget classification; to improve the methods of compilation and consolidation of reporting using modern information systems; to introduce unified approaches to the organization of the work of accounting services of budgetary institutions; to create an integrated information and analytical system of public finance management based on a single plan of accounts and International Accounting Standards in the public sector (Chan 2003; Christiaens and Reyniers 2009).

The countries that have implemented International Accounting Standards for the public sector and accrualbased accounting into the accounting system are usually the best performing countries that conduct managerial reforms (Lüder and Jones 2003). It is possible to find the research on accounting reforms of public sector entities, which were conducted taking into account the impact of unforeseen circumstances (internal and external factors). The researchers studied the definition of the nature and direction of the use of the accrual method and compliance of income and expenditure in the public sector, as well as the definition of clear and understandable rules and unified methodological principles on the mandatory introduction of the accrual method during the estimation of income and expenditure to ensure their openness and transparency (Mostenska et al. 2015). In addition to scientifically grounded research, the elements of the probability theory were also used to verify the impact of unforeseen circumstances (external and internal factors) that could lead to the need to change factors such as the environment, structure and technology of business entities being investigated, namely, public sector entities have been reported recently (Otley 1980; Innes and Mitchell 1990; Ernst \& Young 2012; Ushakov et al. 2017).

In many countries, researchers have been studying public sector reforms in accounting and have also identified difficulties in determining the effectiveness of accounting systems used by public sector entities. The formation of the requirements on the introduction of a new accounting system in the public administration sector on the basis of the practice of economic, legal and accounting life requires the development of its theoretical provisions, which include the identification of its place, role, purpose, subject, objects, functions and tasks. Small businesses should use a cash method in accounting and other enterprises and organizations - the accrual method as the experience of international accounting practices is evidence of it. It is worth noting that more and more countries which used the cash-based methodology or various modified accounting methods in the preparation of public sector accounts are beginning to recognize the advantage of the accrual method and are moving on to its application. Given the shortcomings in the accrual method, the introduction of this principle into the accounting practice of public sector entities requires solving the following problems: automation of the accounting system; clear regulation of the procedure for income accounting, costs and expenses, as well as other objects of accounting. 
In the research, the Italian experience is analyzed, based on the recent studies, which analyzes the process of accounting harmonization among public sector entities and their results, which is carried out on the example of a regional government. At the same time, the study analyzes the Concept of "Accounting on the Basis of the Accrual Principle and Budgeting in the Government - the History of Hessian New Administrative Management (NVS)" and the experience of the State of New South Wales in Australia, Hessian Concept in relation to the harmonization model (Lüder 2013) (Table 1). The application of the accrual principle and the principle of compliance of incomes and expenses in the accounting of entities of the general government sector involves gradual transition in the current accounting practice from the cash method to the accrual method that is fundamental in the International Standards of the Public Sector Accounting that are applied in Italy. The author substantiates that since the cash method involves the recording of all events in the accounts in accordance with the movement of funds, and the accrual method is the recognition of all transactions at the time of their occurrence (at the time of occurrence or the change in the value of assets or liabilities), this contrast of approaches causes the difference in determining the financial result.

Table 1. Main differences between the scientifically significant findings and the Hessian Concept in relation to the harmonization model

\begin{tabular}{|c|c|c|c|}
\hline No. & Main differences & $\begin{array}{l}\text { Concept "Accounting on the } \\
\text { Basis of the Accrual Principle and } \\
\text { Budgeting in the Government - } \\
\text { the History of Hessian New } \\
\text { Administrative Management" }\end{array}$ & Concept of Hessen \\
\hline 1 & 2 & 3 & 4 \\
\hline 1 & $\begin{array}{l}\text { Incentives/intentions of the } \\
\text { reform }\end{array}$ & $\begin{array}{l}\text { Modernization of the government } \\
\text { and accounting system }\end{array}$ & $\begin{array}{l}\text { Modernization of the government } \\
\text { and accounting system }\end{array}$ \\
\hline 2 & $\begin{array}{l}\text { Strategy of implementation and } \\
\text { rapid advancement of the reform }\end{array}$ & $\begin{array}{l}\text { Immediate process of } \\
\text { implementation; the "top-to- } \\
\text { bottom" strategy and "attack" }\end{array}$ & $\begin{array}{l}\text { The process is authoritarian; a "top- } \\
\text { to-bottom" strategy, but more } \\
\text { rational, based on persuasive } \\
\text { training }\end{array}$ \\
\hline 3 & $\begin{array}{l}\text { Impact of public opinion and } \\
\text { private consultants on the reform }\end{array}$ & $\begin{array}{l}\text { Strong controlled consultants, } \\
\text { specialists in the field of } \\
\text { accounting under international } \\
\text { standards }\end{array}$ & $\begin{array}{l}\text { Weak influence, because there is a } \\
\text { diverse experience of accounting } \\
\text { specialists both in accordance with } \\
\text { national and international standards. }\end{array}$ \\
\hline 4 & $\begin{array}{l}\text { Obstacles to the reform } \\
\text { implementation }\end{array}$ & $\begin{array}{l}\text { Incorrect accounting records, } \\
\text { recognition and evaluation of } \\
\text { economic resources, sources of } \\
\text { their formation and inadequate } \\
\text { accounting expertise of the public } \\
\text { sector. }\end{array}$ & $\begin{array}{l}\text { The issue of the implementation of } \\
\text { International Standards of Financial } \\
\text { Reporting during the public sector } \\
\text { reform implementation }\end{array}$ \\
\hline 5 & Impact of the reform & $\begin{array}{l}\text { The result of the reforms is the } \\
\text { introduction of International } \\
\text { Standards of Financial Report for } \\
\text { public sector entities }\end{array}$ & $\begin{array}{l}\text { The reform is still ongoing, so there } \\
\text { are no concrete conclusions }\end{array}$ \\
\hline
\end{tabular}

Source: Own results based on Lüder (2013)

Based on the results of studying the international experience of accounting in the public sector, the following conclusions can be drawn. However, the study of Christensen and Parker (2010) showed some difficulties associated with inertia and, to some extent, resistance to changes in accounting by public sector entities in the state of New South Wales.

Since, under the condition of the application of the cash method, incomes are identified with the cash received from the public sector entity, expenses are identified with spent money. Therefore, the financial result is equated to the change in the amount of cash due to its movement. By the accrual method, the financial result is determined by the difference between the accrued pre-linked causal relationships of income and expenses for certain periods. The Concept of "Accounting on the Basis of the Accrual Principle and Budgeting in the Government - the History of Hessian New Administrative Management (NVS)" has proved that the use of the cash method reduces the economic essence of not only income and expenses but also financial results; at the same time, the application of the accrual method in accounting contributes to the reproduction of the real characteristics of income as a source of increase in the net value of assets, costs as a factor of reducing the net asset value, and hence the financial results as a derivative of the two indicators (Funnell and Cooper 1998; Christensen and Parker 2010). 
In Germany, a new administrative management project in the field of accounting reform was rejected by the Bundestag (Parliament) in July 2010 due to the lack of funding. Later it was modified due to reduced funding. In these economic experiments and projects, Hessen (Germany) gained considerable experience in accounting reforms based on International Accounting Standards for the public sector and the accrual principle, but there were many difficulties and restrictions (Jones and Lüder 2011).

\section{Approaches to the study of accounting reforms}

According to the results of the research of accounting reform of public sector entities, we concluded that this is a process research, which specifies "how the situation changes throughout the time of reform implementation", as the process research examines processes and models in the social context.

In the scientific literature, the elements of the probability theory are considered regarding the experience of many sciences. In the research, the theoretical basis of the probability theory was useful for forming a macroeconomic level of the research. At the first stage of the study, the improvement of the accounting model in the public sector is analyzed, which causes the emergence of a number of features that are characteristic of the market conditions of the functioning of the economic system: an increase in the number of enterprises, the emergence of expanded infrastructure, the decision in terms of uncertainty and risk, etc. Since the theory of probabilities is an integral part of the development of accounting theories, there is an objective need to take into account its impact both at macro- and micro- levels, namely at the level of activity of individual economic entities, their structural units (Haldma and Lääts 2003). At the enterprise level, one of the main subjects of the state sector of the economy, the system of evaluation and presentation of elements of the theory of probability is accounting, because the implementation of the theory of probability through transactions containing elements of risk (in most cases) causes the occurrence of costs that are directly reflected in the accounting. Thus, the development of the theoretical basis for the study of the probability theory in various spheres of activity of public sector entities is one of the priorities both in the theory of transitional economics and in the theory of accounting in public sector entities.

During the second phase of the research analysis, the employees' questionnaires of the public sector in Campania (Italy), responsible for accounting at the enterprise, including the head of the Finance Department and the accountants involved along with the others in this process were handled (Caba-Pèrez et al. 2009; or Laughlin 2012). Moreover, the semi-structured interviews that were based on determined questions and included 20 individual interviews that lasted for one hour each were studied. The analysis is feasible in the research, since a lot of attention is paid to the current phenomena within the framework of real operational activity, which in this case is an in-depth example of the study of the region of Campania in Italy (Yin 2009). These negotiations are aimed at clarifying and making changes to facts and findings based on questionnaire results, where necessary. Thus, the collected data were based on observation, questionnaires, informal negotiations and documents. At the final stage, the collected data can be used on a permanent basis for information analysis.

\section{Main results and comparisons}

The study of reforms in the field of accounting of public sector entities and their comparative analysis revealed the fundamental shortcomings of the cash method and the significant advantages of the accrual method, such as: registration or recognition of expenditures at the time of their implementation; accounting of all resource flows, including those that do not lead to cash flows, but affect the cost of services (depreciation); possibility to receive the information about the state of assets and liabilities; possibility of separate accounting of cash flows and legal obligations associated with it, but not coordinated in the interim period (receipt of funds and the right to receive funds, payment of funds and legal obligation to pay money); possibility of accounting of non-cash transactions, such as mutual settlements, creation and repayment of payables. The disadvantages of the latter of the methods include: the complexity of the accounting process; possibility of occurrence of complications with determination of the term of recognition of income, expenses, range of assets and liabilities, list of long-term financial resources in the absence of clear regulation. Given the certain shortcomings of the accrual method, the introduction of this principle into the accounting practice of entities of the general government sector requires solving the following problems: automation of the accounting system; clear regulation of the accounting procedure first of all recognition of income, expenditures and expenses, as well as other objects of accounting.

An important direction of accounting modernization is the task of improving the system of financial reporting and reporting on the implementation of budgets through updating its methodology, the form of reporting and improvement; approval and implementation of International Accounting Standards for the public sector.

International Accounting Standards for the public sector contain separate requirements for financial reporting, accounting and auditing in the public sector with relevant guidance in the form of explanatory and other material. International Standards for the public sector have the character of recommendations and thus have no higher legal force in relation to officially adopted national standards for the public sector published by public authorities, accounting authorities or professional accounting organizations. When developing International 
Accounting Standards for the public sector, account was taken of those accounting standards that can most effectively be applied to the public sector; national governing bodies in the field of accounting and auditing; professional accounting organizations; other organizations related to financial reporting, accounting and auditing in the public sector and are interested in informing the latter.

When it comes to the reforming process in Italy, the results are the following: The group of Economic Ministries in Italy is represented by the Ministry of Economy and Finance, as well as the Ministry of Economic Development which regulates production, economic activity, energy and mineral resources, is responsible for telecommunication, consumer affairs, tourism, internationalization, creation of incentives for business development and accounting reform of public sector entities. The General Accounting Department provides unified management and coordinates the interaction of the Department of General Accounts with local authorities. The Department is also responsible for internal control over the state budget expenditures and net borrowing from the public sector. Local financial control at the local level will be provided by the local financial management system. The development of such a system requires the creation of a nationwide system of coding income, expenses and debts for each type of organization with anchoring to the classification of the state budget. The functions of the State Department of Accounting have recently been expanded to support the identification of International Accounting Standards for the public sector for the entire system of public administration. The State Department of Accounting consists of a division as well as a specific working group that works on the reform full implementation.

Moreover, other technical committees influence the process of accounting reforms based on International Accounting Standards for the public sector and the accrual principle. The role of committees can be summed up as follows: to conduct surveys, provide additional information to politicians; and conduct advisory work in intergovernmental relations on accounting issues based on international standards and the accrual principle.

The National Association of Business Accounts acts as a technical driver of the reform that develops official interpretations at the national level of International Accounting Standards for the public sector for the reform full implementation. In addition, the members of this association hold consultations and thus directly participate in the formation of the accounting system in accordance with international standards. The Committee of Standards composed of Italian accountants who are also working on this reform implementation. The respondents said that this "informal group" had a significant contribution and effect on the reform. They formulate guiding principles during the stage of "bringing forward of the offer" and the stage of "offer implementation". Consequently, the government community has a significant impact on the accounting reform.

Promoters also play an important role in the reform process and they can be internal or external. Outside promoters predominate in Campania region (Italy). Professional promoters involved in the reform process are partner of KPMG; it was offered (by Regional Decree No. 227 of October 10, 2012) as an official consultant for the "centralized" management of public sector entities, for the introduction of the accounting system based on international standards and the accrual principle (Caperchione 2008).

Prior to the reforms in Italy, the central government, in cooperation with the economic ministries, used the cash method and the accrual method for accounting of public sector entities. Local authorities combine accounting systems in the public sector with both methods. Since budgets are based on accrual accounting, the annual financial statements were compiled in accordance with the principles of the cash accounting method.

The Italian law of 2002 introduces the SIOPE system, intended to receive information from lower levels and other entities by the central government. The SIOPE system is a real-time messaging system for incomes and payments made by treasurers or cashiers of public administration. All public administration bodies (state, regional, local, municipal authorities, educational institutions, health care institutions, etc.) should be connected to the system. The most complex stage of the SIOPE system was the creation of a coding system. The General Accounting Department, the Bank of Italy, the National Institute of Statistics, the National Information Technology Center in Public Administration and, of course, the regional and local authorities were involved in the work on this system.

Implementation obstacles are obstacles that may arise due to the reform delay, obstructing its implementation and may require circumvention and, in extreme cases, even prevent the implementation. In Campania region (Italy), these obstacles were connected, for example, with the "accounting records of business transactions and the sources of business assets formation" (recognition and representation) due to inadequate accounting estimates (Broadbent and Guthrie 2008). There is also a shortage of resources for the modernization of the information technology system. These issues need to be solved during the reform implementation.

The main problem of accounting in the public sector is that many entities conduct accounting by the cash method and, at a minimum, disclose information. Such an approach does not meet the expectations of society, banks, investors and creditors. Given the fact that among the lenders of government organizations there are a lot of banks and private investors, it is not surprising that today we are increasingly hearing the demands to ensure the level of financial transparency in the public sector, similar to that expected from private sector enterprises. Accrual accounting guarantees greater transparency and clarity of public sector financial resources, as well as more thorough control of public debt and liabilities 


\section{Conclusions}

High transparency and clarity of financial resources is a must that should always be present in the public sector. If societies have questions about reporting to public sector entities, it is very important that the government should, as a matter of priority, work to increase the confidence of voters. The government uses taxpayers' money by investing in infrastructure and services development and should report on the use of these funds. To create trust, it is very important for the government to provide accurate and complete information about assets and liabilities, income and expenses. Full details of all operations indicate high responsibility and reasonable leadership, increase confidence and provide a clear and complete understanding of financial implications of economic, political and social decisions. In such information, the emphasis should be on the short-term and long-term effects of decisionmaking, which is impossible in the situation of reporting and disclosure of information only on the flow of funds. Thus, the necessary information can only be obtained through a high-quality, reliable and efficient accounting system based on the accrual principle.

Control of public debt and obligations on real economic consequences. The public debt crisis and its effects, which are still felt, clearly demonstrate failures in the system of governance of the balance sheet in the public sector and underline the inability, for example, of global financial institutions, public debt investors, and credit risk assessment agencies to properly monitor the financial position of the government. In loan financing, it is important to take into account the balance sheet data, since long-term investments can be partially financed by long-term debt, just as a regular household takes mortgages for home purchases. The main priority of the government is to reduce the number of economically unknown factors and significant threats due to inefficient debt management. However, it must be admitted that in itself the size of public debt does not give a complete picture of financial stability. To assess the real economic implications of financial management in the public sector, it is important to know the data for all assets, liabilities and contingent liabilities. In addition, the disclosure of information on all liabilities, including government long-term liabilities (for example, pensions), prompts public sector employees to make long-term decisions and refuse short-term political initiatives. Accounting, reporting, disclosure and, as a consequence, effective control of all state assets and liabilities is possible only within the framework of a high-quality, reliable and efficient accounting system on an accrual basis. The government's task is to work for long-term development and the welfare of future generations. This mission should encourage public sector entities to recognize the importance of transparency and quality of accountability and decision-making in the public sector already today and work to increase it.

Reforms should relate both to state authorities and state-level entities of a lower level. We can see real visions and attitudes of management representatives of business entities to the reforms in the field of accounting.

The organization of accounting under International Accounting Standards for the public sector and the accrual principle provides for: i) accounting and development, approval of an accounting policy in accordance with international standards; ii) development of a working plan of accounting for public sector entities; iii) organization of effective document circulation at public sector enterprises; iv) increasing the skills of accounting employees concerning improving the knowledge of International Accounting Standards for the public sector.

Therefore, in certain aspects, these standards outline the limits of an allowed choice. Consequently, the purpose of accounting policy regulations at the enterprise is to identify those aspects of accounting and reporting, which the company has the right to choose. It appears that the availability of an accounting policy approved by the public sector entity is a direct responsibility of the enterprise senior management established by respective laws and persons responsible for the enterprise accounting. Methodical recommendations on the accounting policy of the public sector entity allow creating a new or improving the existing provision on accounting policies of public sector enterprises simply and efficiently.

\section{References}

Benito B, Brusca I, Montesinos V (2007) The Harmonization of Government Financial Information Systems: The Role of the IPSASs. International Review of Administrative Sciences 73(2):293-317. doi: $10.1177 / 0020852307078424$

Britchenko I, Polishchuk Y, Ivashchenko A (2018) Implementation of ICO European best practices by SMEs. Economic Annals-XXI 169(1-2):67-71. doi: 10.21003/ea.V169-13

Broadbent J, Guthrie J (2008) Public Sector to Public Services: 20 Years of 'Contextual' Accounting Research. Accounting, Auditing \& Accountability Journal 21(2):129-169. doi:10.1108/09513570810854383. 
Caba-Pèrez C, Lopez-Hernandez AM, Ortiz-Rodriguez D (2009) Governmental Financial Information Reforms and Changes in the Political System: The Argentina, Chile and Paraguay Experience. Public Administration 29(5):429-440. doi:10.1002/pad.551

Č́belková I, Abrhám J, Strielkowski W (2015) Factors influencing job satisfaction in post-transition economies: the case of the Czech Republic. International Journal of Occupational Safety and Ergonomics 21(4):448-456. doi: $10.1080 / 10803548.2015 .1073007$

Cañibano L, Mora A (2000) Evaluating the Statistical Significance of 'de Facto' Accounting Harmonization: A Study of European Global Players. European Accounting Review 9(3):349-370. doi:10.1080/09638180020017113

Caperchione E (2008) Tendenze in Atto nel Rinnovamento del Sistema Informativo-Contabile delle Regioni. In: Pezzani F (ed.) A cura di Ripensare il Ruolo e la Governance delle Regioni, Egea, Milano, pp. 7-22.

Chan J (2003) Government Accounting: An Assessment of Theory, Purpose and Standards. Public, Money \& Management 23(1):13-20. doi:10.1111/1467-9302.00336

Christensen M (2002) Accrual Accounting in the Public Sector: The Case of the New South Wales Government. Accounting History 7(2):93-124. doi: 10.1177/103237320200700205.

Christensen M, Parker L (2010) Using Ideas to Advances Professions: Public Sector Accrual Accounting. Financial Accountability and Management 26(3):246-264. doi: 10.1111/j.1468-0408.2010.00501.x

Christiaens J, Reyniers B (2009) Impact of IPSAS on Reforming Governmental Financial Information Systems: A Comparative Study. Working paper, University of Gent, pp. 1-17.

Di Pietra R, Ragioneria Internazionale e 'Armonia' Contabile, 1st edn (Padova, Cedam, 2000), 230 p.

Ernst \& Young (2012) Overview and Comparison of Public Accounting and Auditing Practices in the 27 EU Member States. A report prepared for Eurostat. https://ec.europa.eu/eurostat/documents/1015035/4261806/studyon-public-accounting-and-auditing-2012.pdf/5ad43e2b-2ba7-4b05-afab-d690fc2ad9dd Accessed 26 Aug 2018

European Commission (2013) Report from the Commission to the Council and the European Parliament towards Implementing Harmonized Public Sector Accounting Standards in Member States, Brussels.

Funnell W, Cooper K, Public Sector Accounting and Accountability in Australia, $1^{\text {st }}$ edn. (University of New South Wales Press, Sydney, 1998), 316 p.

Haldma T, Lääts K (2002) Contingencies Influencing the Management Accounting Practices of Estonian Manufacturing Companies. Management Accounting Research 13(4):379-400. doi:10.1006/mare.2002.0197

Hood C (1995) The 'New Public Management' in the 1980s: Variations on a Theme. Accounting, Organizations and Society 20 (2-3):93-109. doi: 10.1016/0361-3682(93)E0001-W

Innes J, Mitchell F (1990) The Process of Change in Management: Some Field Study Evidence. Management Accounting Research 1(1):3-19. doi:10.1016/S1044-5005(90)70042-X

Jackson A, Lapsley I (2003) The Diffusion of Accounting Practices in the New 'Managerial' Public Sector. The International Journal of Public Sector Management 15(5):359-372. doi:10.1108/09513550310489304

Jones R, Lüder K (2011) The Federal Government of Germany's Circumspection Concerning Accrual Budgeting and Accounting. Public Money \& Management 31(4):265-270. doi:10.1006/mare.2002.0197

Kalyugina S, Strielkowski W, Ushvitsky L, Astachova E (2015) Sustainable and secure development: facet of personal financial issues. Journal of Security \& Sustainability Issues 5(2):297-304. doi: 10.9770/jssi.2015.5.2(14)

Kunitsyna N, Britchenko I, Kunitsyn I (2018) Reputational risks, value of losses and financial sustainability of commercial banks. Entrepreneurship and Sustainability Issues 5(4):943-955. doi: 10.9770/jesi.2018.5.4(17)

Lapsley I, Wright E (2004) The Diffusion of Management Accounting Innovations. Management Accounting Research 15(3):355-374. doi:10.1006/mare.2002.0197.

Laughlin R (2012) Debate: Accrual Accounting: Information for Accountability or Decision Usefulness? Public Money \& Management 32(1):45-46. http://dx.doi.org/10.1080/09540962.2012.643056

Lüder K (2013) Accrual Accounting and Budgeting in Government-A History of the Hessian 'New Administrative Management (NVS)' Project, Paper Presented to the 14th Biennial CIGAR Conference, Birmigham, United Kingdom. 
Lüder K, Jones R, Reforming Governmental Accounting and Budgeting in Europe, $1^{\text {st }}$ edn. (Fachverlag Moderne Wirtschaft, Frankfurt, 2003). www.pwc.com/gx/eng/about/ind/gov/waschzettel_Euro-Cigar.pdf. Accessed 28 Aug 2018

Masiulevičius A, Lakis V. (2018) Differentiation of performance materiality in audit based on business needs. Entrepreneurship and Sustainability Issues 6(1): 115-124. doi:10.9770/jesi.2018.6.1(9)

Mostenska T (2015) Informal market as a result of shadow economy. Czech Journal of Social Sciences, Business and Economics 4(2):23-29. doi: 10.24984/cjssbe.2015.4.2.3

Moyseyenko I, Ryvak N (2016) Indirect taxes in the mechanism of state regulation. International Economics Letters 5(2):63-71. doi: 10.24984/iel.2016.5.2.4

Otley D (1980) The Contingency Theory of Management Accounting: Achievement and PrognosisAccounting, Organizations and Society 5(4):413-428. doi:10.1016/0361-3682(80)90040-9

Pettigrew A (1997) What Is a Processual Analysis. Scandinavian Journal of Management 13(4):337-348. doi:10.1016/S0956-5221(97)00020-1.

Subačienė R, Alver L, Brūna I, Hladika M, Mokošová D, Molín J (2018) Evaluation of accounting regulation evolution in selected countries. Entrepreneurship and Sustainability Issues 6(1):139-175. doi: 10.9770/jesi.2018.6.1(11)

Ushakov D, Bandurina N, Shkodinsky S (2017) Country's Welfare as an Efficiency Factor in Fiscal Policy Promoting Economic Growth. Montenegrin Journal of Economics 13(2):121-127. doi: 10.14254/1800$5845 / 2017.13-2.7$

Van Der Tas L, Raffournier B, Haller A, Walter P (1992) Measuring International Harmonization and Standardization: A Comment. Abacus 28(2):211-216. doi:10.1111/j.1467-6281.1992.tb00281.x

Yin R, Case Study Research Design and Methods, $1^{\text {st }}$ edn. (Sage Ltd, London, 2009), 219 p. 